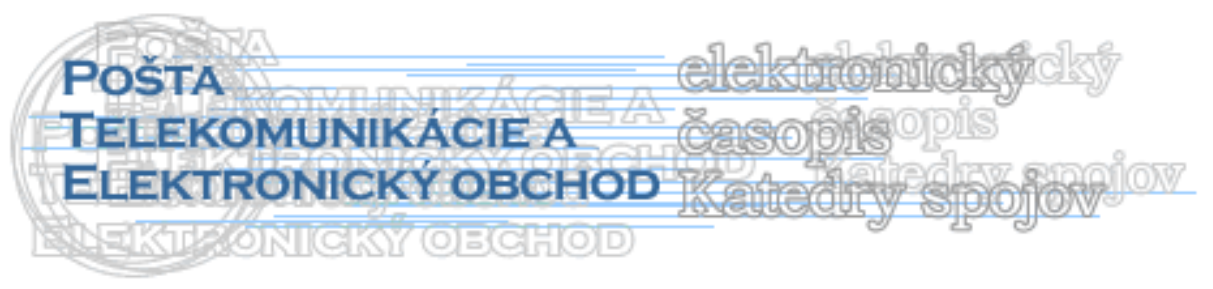

\title{
EFEKTÍVNY TIME MANAŽMENT
}

\author{
Lubomír Bombala*
}

Úvod

Správny time manažment je jednou z podstatných znalostí, ktorú si vedúci pracovníci môžu postupne osvojit'. Každý z nás disponuje tým istým počtom hodín za deň a nijakým úsilím to nemôžeme zmenit'. To, čo dokážeme ovplyvnit' úplne spol'ahlivo, je spôsob, ako tento čas strávime. V tejto súvislosti bude správne citovat' priamo Stephena Coveyho, ktorý o time manažmente hovorí nasledovné: "Som osobne presvedčený, že najlepšie uvažovanie v oblasti time manažmentu môže byt' zachytené v jednoduchej fráze: organizovat' a vykonávat' na základe priorít [3].”

\section{Definície}

Pre potreby tohto článku je najprv potrebné zadefinovat', čo rozumieme pod pojmom efektívnost' a time manažment, aby sme mohli d’alej rozvinút' teóriu efektívneho time manažmentu. V tejto súvislosti je vhodné použit' definíciu efektívnosti, ktorú predstavil Stephen Covey [3]. Definuje ju ako vyváženost' medzi P (produkciou) a PC (produkčnou schopnost'ou). Jej základný princíp vysvetl’uje na príklade husi, ktorá znáša zlaté vajcia. Pokial' chceme dosiahnut' vysokú produkciu zlatých vajec, nie je to možné iba neustálym odoberaním vajec, či nepodaj jej utratením, mysliac si, že hus ich obsahuje. Našu pozornost' si vyžaduje aj hus sama a jej produkčná schopnost', ktorá je podmienená tým, aké podmienky je vytvoríme, ako sa o ňu staráme.

David Allen v súvislosti s time manažmentom upozorňuje na skutočnost', že nemôžeme manažovat' čas a problém je nesprávne označovaný, to čo skutočne môžeme ovplyvnit' je naša aktivita $\mathrm{v}$ čase t.j. definovat' výstupy a aktivity, ktoré vykonáme v určitom čase [1].

V time manažmente považujeme za efektívne splnenie dôležitých úloh, ktoré budú fungovat' ako prevencia naliehavých problémov a ktoré nám umožnia venovat' sa všetkým aspektom nášho života nielen pracovného, ale aj osobného. Tieto aspekty by sme si mali zaznamenat', tak aby sme na žiadny aspekt nezabudli a boli schopní priradit' im prioritu v časovom pláne.

\section{Generácie time manažmentu}

\footnotetext{
* Ing. L’ubomír Bombala, DHL IT Services Europe, V Parku 2308/10, 14800 Praha 4, ext. doktorand, Katedra spojov, FPEDAS, ŽU v Žiline

tel: $\quad+420288802185$

e-mail: lubomir.bombala@dhl.com
} 
Stephen Covey sa vo svojom tret’om návyku efektívnych l’udí - dôležité veci sú prvoradé - zaoberá viacerými otázkami time manažmentu. Základnou myšlienkou time manažmentu je

organizovat' a vykonávat' všetko na základe priorít. Táto myšlienka reprezentuje evolúciu troch generácií teórie time manažmentu, návodom na správny time manažment môže byt' široký súbor prístupov a materiálov.

V oblasti time manažmentu, podobne ako aj v iných oblastiach l'udského jestvovania, platí pravidlo, že každá generácia stavia na generácii pred ňou, pričom každá nás posúva d’alej z pohl'adu väčšej kontroly nad našim životom.

Prvá generácia môže byt’ charakterizovaná poznámkami a zoznamom úloh. Vyznačuje sa úsilím dat' podobu rozpoznania a kompletnosti mnohým požiadavkám kladeným na náš čas a energiu.

Druhá generácia už využíva kalendáre a záznamníky stretnutí. Táto generácia sa snaží nazriet' do budúcnosti, plánovat' udalosti a aktivity.

Tretia generácia popisuje súčasný stav v tejto oblasti. Predchádzajúce generácie dopĺn̆a dôležitou myšlienkou prioritizácie, vyjasňovaním hodnôt a porovnávaním relatívnej dôležitosti aktivít založených na ich vzt'ahu k týmto hodnotám. Naviac sa zameriava na stanovenie ciel'ov, špecificky dlhodobých, strednodobých a krátkodobých s ohl'adom na množstvo času a energie, ktoré bude potrebné v súlade s hodnotami. Taktiež zahŕňa koncepciu denného plánu, prípravy špecifických plánov, ktoré umožnia zrealizovat' tieto ciele a aktivity s ohl'adom na ich dôležitost'.

Hoci bola tretia generácia výrazným prínosom, l'udia si začali uvedomovat', že presné rozvrhnutie a riadenie času sú často kontraproduktívne. Sústredenie sa na efektivitu vytvára očakávania, ktoré sú v rozpore s príležitost'ami vyvinút' bohaté vzt'ahy, vyplnit' l'udské požiadavky a vychutnat' spontánne momenty na dennej báze. Výsledkom toho bolo, že mnoho l'udí sa cítilo uzatvorených prísnym poriadkom time manažmentu a plánovania, cítili sa príliš obmedzovaní a začali sa vracat' k prvej a druhej generácii, aby tak udržali kvalitu vzt'ahov, splnili l'udské požiadavky a vychutnali spontánnost' momentov na dennej báze.

Potom sa objavila štvrtá generácia time manažmentu, ktorá je druhovo iná. Rozoznáva, že time manažment je v skutočnosti nesprávne pomenovanie a výzvou nie je manažovat' čas, ale manažovat' seba samého. Satisfakcia je funkciou ako očakávania, tak aj realizácie. Očakávania a satisfakcia sú v oblasti aktivít, ktoré môže človek svojím konaním ovplyvnit'.

Štvrtá generácia sa sústred’uje na prevenciu, zjednodušuje vzt'ahy a dosahuje výsledky, nesústred'uje sa na veci a čas. V skratke udržiava rovnováhu medzi P a PC t.j. produkciou a produkčnou schopnost'ou.

\section{Nástroje time manažmentu}

V súvislosti s time manažmentom sa v literatúre uvádzajú rozličné nástroje, ktoré majú pomôct' vedúcim pracovníkom organizovat' ich čas na základe priorít.

\section{1. nástroj je tzv. mreža alebo matica time manažmentu}

Matica sa sústred'uje na dve základné dimenzie time manažmentu a to sú: naliehavost' a dôležitost' úloh, ktoré si vyžadujú našu pozornost'. 
Tab 1.: Matica time manažmentu

\begin{tabular}{|c|c|c|}
\hline & Naliehavé & Nenaliehavé \\
\hline Dôležité & $\begin{array}{l}\text { KVADRANT I } \\
\text { (kvadrant potrebnosti) } \\
\text { krízy, urgentné problémy, } \\
\text { projekty založené na } \\
\text { deathlines }\end{array}$ & $\begin{array}{l}\text { KVADRANT II } \\
\text { (kvadrant kvality } \\
\text { a personálneho vedenia) } \\
\text { prevencia, aktivity } \\
\text { vytvárajúce produkčnú } \\
\text { schopnost' do budúcnosti, } \\
\text { budovanie vzt'ahov, } \\
\text { rozpoznávanie nových } \\
\text { príležitostí, plánovanie, } \\
\text { tvorenie nanovo, zotavenie }\end{array}$ \\
\hline Nedôležité & $\begin{array}{l}\text { KVADRANT III } \\
\text { (kvadrant omylov) } \\
\text { prerušenia, rutinné } \\
\text { telefonáty, pravidelná } \\
\text { elektronická pošta, nejaké } \\
\text { správy, nejaké mítingy, } \\
\text { populárne činnosti }\end{array}$ & $\begin{array}{l}\text { KVADRANT IV } \\
\text { (kvadrant plytvania) } \\
\text { triviálnosti, } \\
\text { zaneprázdnenost', nejaká } \\
\text { pošta, nejaké telefonáty, } \\
\text { činnosti plytvajúce časom, } \\
\text { príjemné aktivity }\end{array}$ \\
\hline
\end{tabular}

Každá aktivita, ktorú vykonávame v priebehu dňa môže byt' zaradená do jedného zo 4 kvadrantov:

1. naliehavé a dôležité

2. nenaliehavé a dôležité

3. naliehavé a nedôležité

4. nenaliehavé a nedôležité

Pozornost' štvrtej generácie time manažmentu môžeme zachytit' v matici time manažmentu. V zásade strávime čas jedným zo štyroch spôsobov.

Z matice môžeme vidiet' dva faktory, ktoré definujú aktivitu: naliehavost' a dôležitost'. Naliehavá aktivita je tá, ktorá si vyžaduje okamžitú pozornost', vyžaduje si našu okamžitú aktivitu. Môžete strávit' hodiny prípravou materiálov a byt' na ceste do kancelárie kolegu, aby ste prediskutovali dôležité problémy, ak však začne zvonit' telefón zatial' čo ste tam, vo všeobecnosti ho uprednostníte pred osobnou návštevou.

Naliehavé veci sú obyčajne viditel'né. Tlačia na nás a vyžadujú si akciu. Často je príjemné ukazovat', že ich vykonávame. Sú často priamo pred nami a často sú príjemné, l'ahké na vykonanie, dokonca to môže byt' zábavné ich vykonávat', ale často platí, že nie sú dôležité.

Dôležitost' na druhej strane má do činenia s výsledkami. Ak je niečo dôležité, malo by to byt' v súlade s našimi hodnotami a ciel'mi, ktoré majú vysokú prioritu.

Obyčajne reagujeme na naliehavé záležitosti. Dôležité záležitosti, ktoré nie sú naliehavé vyžadujú viac iniciatívy, viac proaktivity. Musíme konat', aby sme sa uchopili príležitosti, aby sa niečo dialo. Ak však nemáme jasnú predstavu o tom, čo je dôležité, o výsledkoch, ktoré chceme dosiahnut' v živote, l'ahko sa odkloníme a reagujeme na naliehavé.

Pozrime sa teraz bližšie na 4 kvadranty matice time manažmentu. Prvý kvadrant je súčasne naliehavý a dôležitý. Zaoberá sa významnými aktivitami, ktoré si vyžadujú okamžitú pozornost'. Zvyčajne označujeme aktivity prvého kvadrantu ako krízy alebo problémy. Všetci máme vo svojich životoch aktivity prvého kvadrantu, avšak prvý kvadrant je schopný zahltit' 
mnohých l'udí. Sú to krízoví manažéri, problémovo mysliaci l'udia, ktorí sa riadia termínmi ukončenia projektov a aktivít.

Tak dlho, ako sa budete koncentrovat' na prvý kvadrant, začne sa tento kvadrant rozrastat', až vás ovládne. Problémy sa budú objavovat' znovu a znovu, budu vás zat'ažovat' až vás úplne vyčerpajú.

Niektorí l'udia sú doslova bití problémami každý deň. Jediný spôsob, ako im uniknút', je utiect' k nepodstatným a nenaliehavým aktivitám štvrtého kvadrantu. Ked' sa pozrieme na ich maticu, 90 percent ich času je v prvom kvadrante a zvyšných 10 percent je $v$ štvrtom kvadrante s iba zanedbatel'nou pozornost'ou na druhý a tretí kvadrant. Toto je spôsob života l'udí riadených krízami znázornený na obr. 1.

\begin{tabular}{|c|c|}
\hline \multirow[b]{2}{*}{$\begin{array}{l}\text { Výsledky: } \\
\text { - Stres } \\
\text { - Vyhorenie } \\
\text { - Krízov́manažment } \\
\text { - Ustavičnéhasenieohňa }\end{array}$} & II \\
\hline & IV \\
\hline III & \\
\hline
\end{tabular}

Obr 1.

Ďalšia skupina l’udí strávi vel'kú čast' času naliehavými, ale nepodstatnými aktivitami tretieho kvadrantu, mysliac si naivne, že sú v prvom kvadrante. Strávia čas reagovaním na naliehavé problémy považujúc ich za dôležité. Skutočnost' je ale taká, že naliehavost' týchto problémov je založená na prioritách a očakávaniach iných. Sústredenie sa na tretí kvadrant znázorňuje obr. 2.

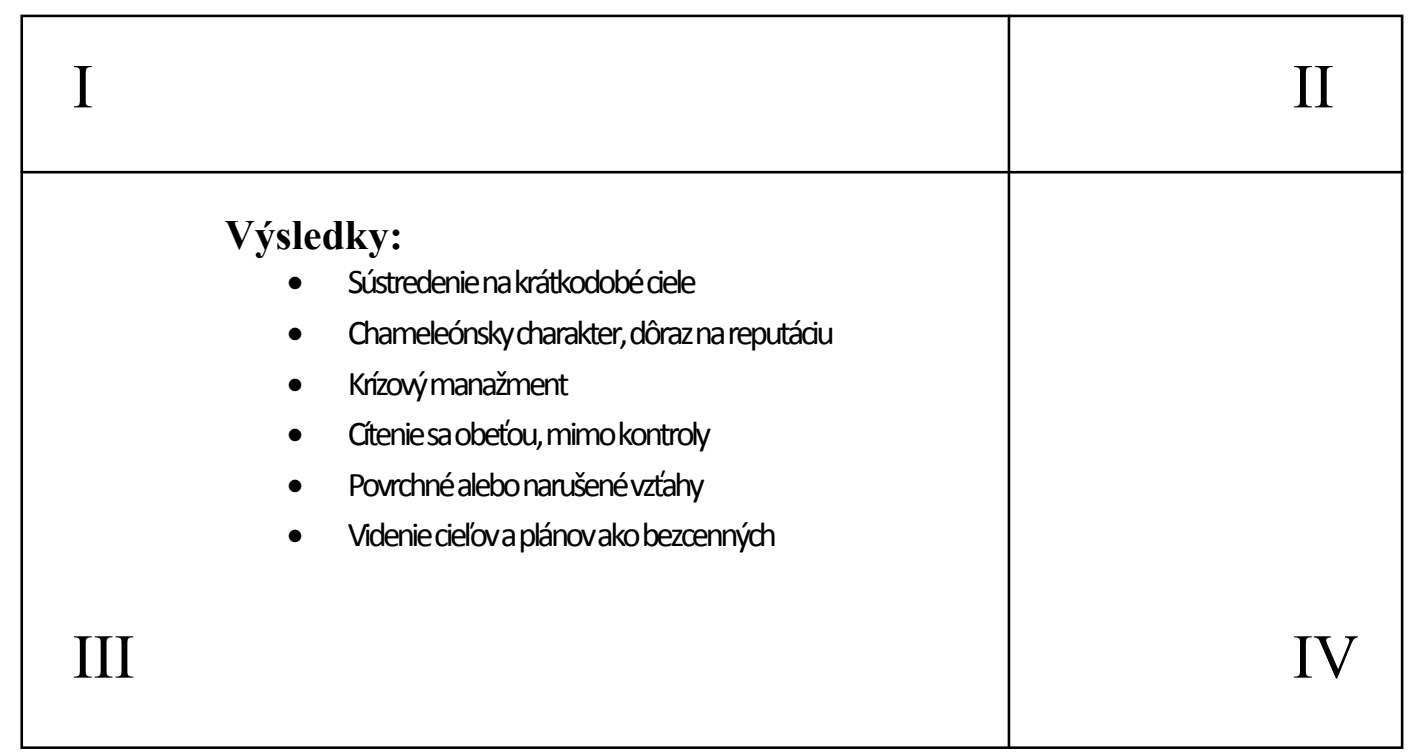

Obr. 2. 
L’udia, ktorí strávia väčšinu svojho života skoro výlučne v tret’om a štvrtom kvadrante vedú nezodpovedný život. Ich matica time manažmentu je znázornená na obr. 3.

\begin{tabular}{|c|c|c|}
\hline I & & II \\
\hline III & $\begin{array}{l}\text { Výsledky: } \\
\text { - Totálnanezodpovednost' } \\
\text { - Prepustený z práce } \\
\text { - Závislost'nadruhýchainštitúciách vzákladných } \\
\text { otázkach }\end{array}$ & \\
\hline
\end{tabular}

Obr. 3.

Efektívni l'udia sa držia aj mimo tretieho a štvrtého kvadrantu, pretože či už sú aktivity naliehavé alebo nie, stále nie sú dôležité. Darí sa im zmenšit' aj čas strávený v prvom kvadrante a venujú ho druhému kvadrantu. Matica efektívneho time manažmentu je znázornená na obr. 4.

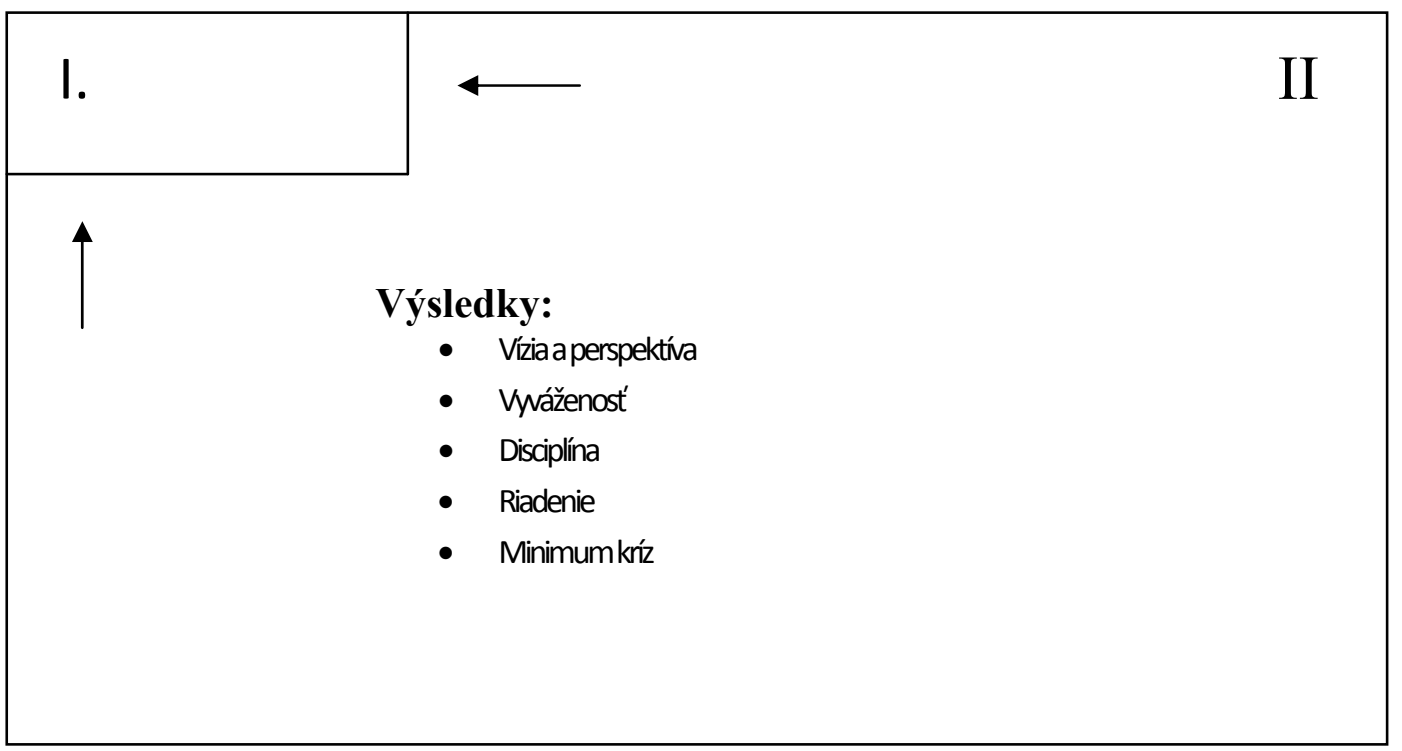

Obr. 4.

\section{Druhý kvadrant}

Celkový efekt aktivít $\mathrm{v}$ druhom kvadrante bude nasledovný: strávite väčšinu vášho času delegovaním, trénovaním, prípravou prezentácií na mítingy, minimalizujete počet telefonátov. Pri využití tohto prístupu v dlhšom období, čo je v podstate prístup zameraný na zvyšovanie PC (production capacity), sa počet naliehavých problémov patriacich do prvého kvadrantu radikálne zmenší. 
Samozrejme, že nejaký čas sa musí vždy strávit' aj v prvom kvadrante, pretože aj tie najlepšie plány sa čas od času nepodarí zrealizovat'. Sústredením sa na druhý kvadrant ho však dokážete tak ovládnut', že to obmedzí počet stresových situácií, ktoré negatívne ovplyvňujú vašu schopnost' robit' správne rozhodnutia a v konečnom dôsledku škodia aj zdraviu.

Samozrejme, že tento prístup si vyžaduje vel'kú trpezlivost' a odolnost' a niekedy sa jednoducho nedá použit' $z$ toho alebo iného dôvodu. Jeho aplikáciou a vybudovaním povedomia o tomto prístupe u vašich kolegov časom postrehnete výrazné zlepšenie výkonnosti vzhl'adom na strávený čas.

Druhý kvadrant vám umožní vytvorit’ kreatívne a zaujímavé riešenia, ktoré umožnia vyhnút' sa krízam prvého kvadrantu a vytvoria priestor na využitie iniciatívy.

Zodpovedajme na túto otázku: Akú jednu vec môžete urobit' vo vašom osobnom či profesionálnom živote, ktorej vykonávaním na pravidelnej báze dosiahnete výrazne pozitívnu zmenu vo vašom živote? Zmeny, akokol'vek ich nazveme sú aktivitou druhého kvadrantu. Efektívni, proaktívni l'udia strávia väčšinu svojho života aktivitami v druhom kvadrante

Druhý kvadrant je srdcom efektívneho time manažmentu. Zaoberá sa problémami, ktoré nie sú naliehavé, ale sú dôležité. Zaoberá sa otázkami ako sú nadväzovanie vzt’ahov, písanie deklarácie mission statement, dlhodobé plánovanie, tréning, preventívna udržba, príprava - všetky veci, ktoré potrebujeme urobit', ale zriadkakedy sa im venujeme, lebo nie sú dôležité.

Na tomto mieste môžeme parafrázovat' Petra Druckera: „efektívni l’udia nie sú založení na problémoch, ale na príležitostiach. [1]“ Vyhl'adávajú príležitosti a vyhýbajú sa problémom. Myslia preventívne. Majú skutočné problémy prvého kvadrantu a riešia krízy, ktoré vyžadujú okamžitú pozornost', ale ich množstvo je neporovnatel'ne menšie. Udržiavajú rovnováhu medzi $\mathrm{P}$ a PC sústredením sa na dôležité, ale nie naliehavé aktivity, vysoko podporujúce tvorbu PC, ležiace $\mathrm{v}$ druhom kvadrante. V súvislosti s tým sa hovorí aj o jednom z pravidiel time manažmentu, ktoré znie, že 80 percent výsledkov plynie z 20 percent aktivít.

Aktivity z druhého kvadrantu sa skutočne tažko realizujú, nie sú naliehavé, a pritom stále zostávajú urgentné veci v prvom a tret'om kvadrante, ktoré na vás tlačia. Avšak aktivity druhého kvadrantu vám smerom do budúcnosti ponúkajú najväčší predpoklad na rast a posun dopredu.

\section{Paradigma druhého kvadrantu}

Klúčom k efektívnemu manažmentu seba alebo iných prostredníctvom delegovania nie je nástroj alebo vonkajší faktor. Je to vnútorný faktor a spočíva $\mathrm{v}$ paradigme druhého kvadrantu, ktorá vám umožňuje vidiet' prostredníctvom šošoviek dôležitosti a uprednostňuje dôležité pred naliehavým.

V súvislosti s time manažmentom sa Stephen Covey snaží uplatnit' tretí návyk a to Dôležité veci sú prvoradé. Na základe toho doporučuje tyždenné plánovanie namiesto denného.

Každú nedel'u sa pozrite na svoje úlohy a ciele z deklarácie poslania a prirad’te aktivity počas týždňa, ktoré ich uskutočnia. Pokojne ich môžete spojit' viac do jednej, t.j. ak vaším poslaním je byt' dobrým otcom, manželom a mat' dobrú kondíciu, potom štvrtok popoludní, ked' máte všetci vol'no, pôjdete behat's manželkou a synom. 


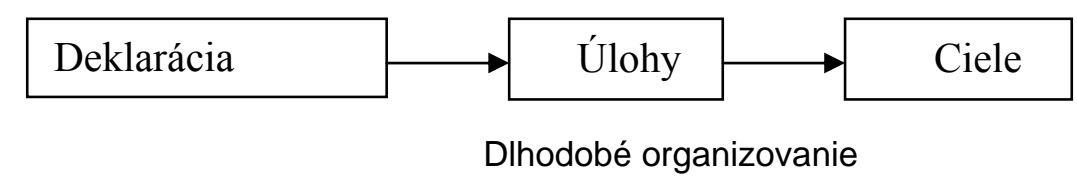

Obr. 5.

Týždenné organizovanie podla Stephena Coveyho spočíva v stanovení ciel’ov a úloh a preložení každého ciel'a do špecifickej činnosti v špecifický deň, teda vytvorenie týždenného rozvrhu. Týždenný rozvrh potom obsahuje úlohy a stanovené ciele pre každú úlohu. Rozvrh pracuje s najmenšou jednotkou hodina, má stanovené týždenné priority, denné priority, stretnutia a záväzky.

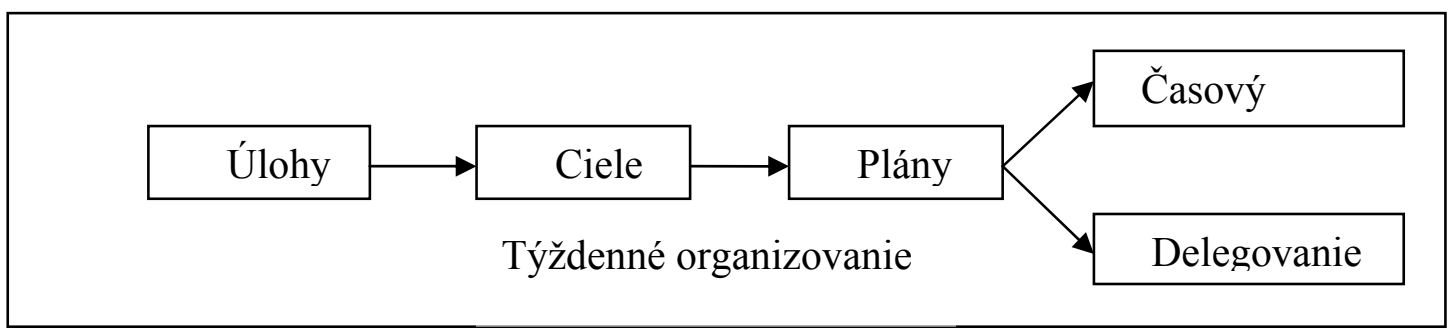

Obr. 6.

Uvedomele sa snažte maximalizovat' čas strávený v druhom kvadrante. Alokujte vo vašom diári čas na tieto činnosti. Táto aktivita zredukuje aktivity v prvom kvadrante, pretože mnohé z nich mohli byt' vykonané už v druhom kvadrante, ale skôr ako nastali v prvom. Môžete takisto zredukovat' čas strávený v tret'om kvadrante zlepšením vašich systémov a procesov pre prípad rušivých situácií, môžete takisto zredukovat' aktivity štvrtého kvadrantu, bud' tým, že ich jednoducho vylúčite alebo zmeníte ich povahu, aby boli viacej produktívne.

\section{2. nástroj: Plánovanie ciel’ov}

Vel'a l'udí má denný zoznam činností, ktoré musia urobit' a ktoré môžu utriedit' podl'a priority a na základe toho organizovat' svoj čas a prácu. Avšak, aby ste dokázali sústredit' svoj čas na to, čo je skutočne dôležité a je v súlade s vašimi ciel'mi, budete potrebovat': uvedomenie si priorít a zaznamenat' písomne, čo chcete dosiahnut' naprieč kl'účovými úlohami a rozličnými čast'ami vášho života. Niektorí vedúci pracovníci môžu byt' prekvapení stanovením ciel'ov pre rodinný život, ale tieto ciele môžu byt' napríklad o hl'adaní kvalitnejšie stráveného času s rodinou, skôr ako dosiahnutie nejakého špecifického ciel'a. Keby ste si stanovili iba ciele pre časti života, ktoré sa týkajú práce a profesionálneho rastu, mohlo by to výrazne obmedzit' d'alšie podstatné elementy vášho života.

Zapíšte si 3 alebo aj 4 mesačné plány pokroku, ktorý chcete dosiahnut' v napíňaní týchto ciel'ov. Tomuto prispôsobte vaše denné a mesačné plánovanie. Nebud’te príliš ambiciózni, pretože toto môže viest' k pocitom frustrácie, no zároveň si stanovte aspoň jeden alebo dva mil'níky, ktoré vás budú vyzývat' k vyššej aktivite v oblasti najdôležitejších ciel'ov. 


\section{3. nástroj sú tipy pre správny time manažment:}

- Vediet', čo je dôležité - napísat' si klúčové ciele ku ktorým smerujeme (Toto je možné aplikovat' na všetky sféry nášho života)

- Vedome plánovat' svoj čas : využitím troch alebo štyroch mesačných a týždenných plánov

- Vybrat' si metódu komunikácie : telefón, dopis, mítingy alebo e-mail

- Písat' si do diára ceruzkou, pomôže to znížit' negatívny pocit zo zmeny plánu

- Vyhnút' sa vedeniu na základe plánu $\mathrm{v}$ diári. To, že je niečo $\mathrm{v}$ diári napísané ešte neznamená, že nemôžete robit's časom niečo iné

- To najlepšie, čo môžete urobit' s vašim časom je naplánovanie aktivity z druhého kvadrantu na tento čas

- Urobte 10 minút vašou najväčšou jednotkou - vel’a úloh sa dá stihnút' za šetrných 10 minút, vrátane krátkej relaxačnej pauzy

- Periodicky preverujte vašu časovú efektívnost' z pohl'adu mapy kvadrantov a jej súlad s ciel'mi.

\section{Čo to stojí povedat" "Nie"?}

Jediný spôsob ako na začiatku získat' čas pre druhý kvadrant je z tretieho a štvrtého kvadrantu. Nemôžete ignorovat' dôležité a naliehavé aktivity prvého kvadrantu, hoci sa ich počet zmenší s využitím prevencie a prípravy druhého kvadrantu, ale počiatočný čas pre druhý kvadrant musíte čerpat' z tretieho a štvrtého.

Musíte proaktívne pracovat' na druhom kvadrante, pretože prvý a tretí kvadrant “pracujúc" na vás. Povedzte "áno“ dôležitým prioritám druhého kvadrantu a naučte sa povedat' "nie“ iným aktivitám, niekedy zretel’ne urgentným.

Uvedomme si, že stále hovoríme niečomu "nie“. Často sú to zretel'ne na prvý pohl'ad naliehavé veci v našom živote, pravdepodobne základné a dôležité. Hoci naliehavé je dobré, môže vám to bránit' dosiahnut' to najlepšie, zabránit' vášmu unikátnemu príspevku, ked' to dovolíte.

Existuje vel'a l'udí, ktorí rozoznávajú hodnotu aktivít druhého kvadrantu v ich živote, či ich už identifikujú alebo nie. Pokúšajú sa dat' prioritu týmto aktivitám a integrovat' ich do svojho života prostredníctvom sebadisciplíny. Bez principiálneho centra a deklarovania poslania však nemajú dostatočnú podporu, aby v tomto úsilí obstáli. Dôvodom je, že bez toho, aby ich aktivity vychádzali z princípov, ktorými sa riadia a ich poslania, nie je možné povedat' nie niektorým aktivitám a pracovat' iba na druhom kvadrante.

\section{Výhody štvrtej generácie}

Jeden $\mathrm{z}$ dôvodov prečo l'udia odmietajú používat' nástroje tretej generácie time manažmentu je, že strácajú spontánnost'. Stávajú sa strnulí a neflexibilní. Podriad’ujú sa plánom, pretože výkonnostná paradigma tretej generácie je v rozpore s princípom, že l'udia sú dôležitejší ako veci.

Štvrtá generácia rozoznáva tento princíp. Rozoznáva, že prvou osobou, ktorú musíme zvažovat' v intenciách efektívnosti radšej ako výkonnosti ste vy. Podporuje vás v trávení času $\mathrm{v}$ druhom kvadrante, umožňuje pochopit' a orientovat' život na princípy, dáva jasne vyjadrenie účelov a hodnôt, ktorými chcete riadit' svoje denné rozhodnutia. Pomáha tak vytvorit' vyváženost' vo vašom živote. Pomáha vám prekročit' limity denného plánovania, 
organizovat', plánovat' v kontexte týždňa. Ked' sa objaví vyššia hodnota, ktorá je v konflikte s tým, čo ste plánovali, podporuje vás využitím vašej vlastnej uvedomelosti a pomáha udržat' súlad s princípmi a účelmi, ktoré ste si determinovali ako najdôležitejšie.

Aby sme boli efektívni, musíme sa vyhýbat' aktivitám kvadrantov III and IV. Aby sme to dosiahli, je nevyhnutné povedat' nie sebe samému, ale aj iným, pokial' vykonávajú aktivitu $\mathrm{v}$ týchto kvadrantoch a navrhnút' radšej aktivity z druhého kvadrantu.

Štvrtá generácia je podstatne rozvinutejšia ako tretia vd’aka 5 dôležitými výhodám:

1. orientuje sa na princípy. Vytvára centrálnu paradigmu, ktorá vás podporuje vidiet' váš čas v kontexte toho čo je naozaj dôležité a efektívne.

2. uvedomelo-orientovaná. Dáva príležitost' organizovat' váš život v súlade s najlepšími schopnost’ami $\mathrm{v}$ harmónii s najhlbšími hodnotami, ale súčasne dáva slobodu podriadit’ rozvrh vyšším hodnotám.

3. definuje vašu unikátnu misiu, vrátane hodnôt a dlhodobých ciel'ov. Toto dáva smerovanie a účel spôsobu, ako trávite každý deň.

4. pomáha vám vyvážit' váš život identifikovaním úloh a stanovením ciel’ov a plánovaním aktivít v klúčových úlohách každý týždeň.

5. umožňuje väčší kontext čo je dosiahnuté týždenným plánovaním (s dennou adaptáciou, ak je potrebná), umožňuje dosahovat' viac ako sú limitujúce perspektívy jedného dňa a dávat' vás do súladu $\mathrm{s}$ vašimi najhlbšími hodnotami prostredníctvom kontroly kl'účových úloh.

Z týchto piatich výhod vyplýva primárny dôraz na vzt’ahy a výsledky, sekundárny dôraz na čas.

\section{Delegovanie: Zvyšovanie P (produkcie) a PC (produkčnej schopnosti)}

Všetko čo robíme, môžeme uskutočnit' prostredníctvom delegovania - bud' času alebo iným l’ud'om. Ak delegujeme čas, hovoríme spravidla o výkonnosti. Ak delegujeme iným l'ud'om, hovoríme o efektivite.

Mnoho l'udí odmieta delegovat' iným l'ud'om, pretože majú pocit, že to zoberie vel'a času, úsilia a že svoju prácu urobia lepšie sami. Správne delegovanie je však jednou z najlepších aktivít druhého kvadrantu, ktorá existuje.

Presun zodpovednosti na iných skúsených a trénovaných l'udí otvára priestor venovat' energiu iným dôležitým aktivitám. Delegovanie znamená rast, ako pre individuálov, tak pre organizácie.

Covey v tejto súvislosti uvádza skvelý príklad o delegovaní starostlivosti o trávnik svojmu synovi. Hovorí mu iba jednoducho, že ho chce mat' zelený a čistý, pričom syn môže používat' akékol'vek nástroje a prostriedky vrátane Coveyho samotného. Ked' deleguje túto prácu, tak nehovorí synovi, čo má robit' (čo by bolo zabitím husy), dáva mu iba víziu a dáva synovi šancu vybrat' sa vlastnou cestou naplnenia ciel'a.

\section{Záver}

Time manažment a jeho nástroje môžeme záradit' k nástrojom na zvyšovanie produktivity jednotlivca i celej organizácie. Organizovanie a vykonávanie na základe priorít nám z dlhodobého pohl'adu umožní ušetrit' vel'ké množstvo času a sústredit' sa na reálne problémy, resp. problémy predvídat' a predchádzat' im. V každom prípade je potrebné vediet' robit' rozhodnutia aj na dennej báze, v prípade potreby improvizovat' a urobit' zásadné zmeny v pláne pokial' si to okolnosti vyžadujú. 


\section{Literatúra}

[1] ALLEN, D.: Ready for Anything - 52 Productivity Principles for Work and Life, Viking Books, New York, 2003

[2] CAUNT, J.: Time management - jak hospodařit s časem, Computer Press, 2007

[3] COVEY, R. S.: The 7 habits of highly effective people, Free press, New York, 2004 